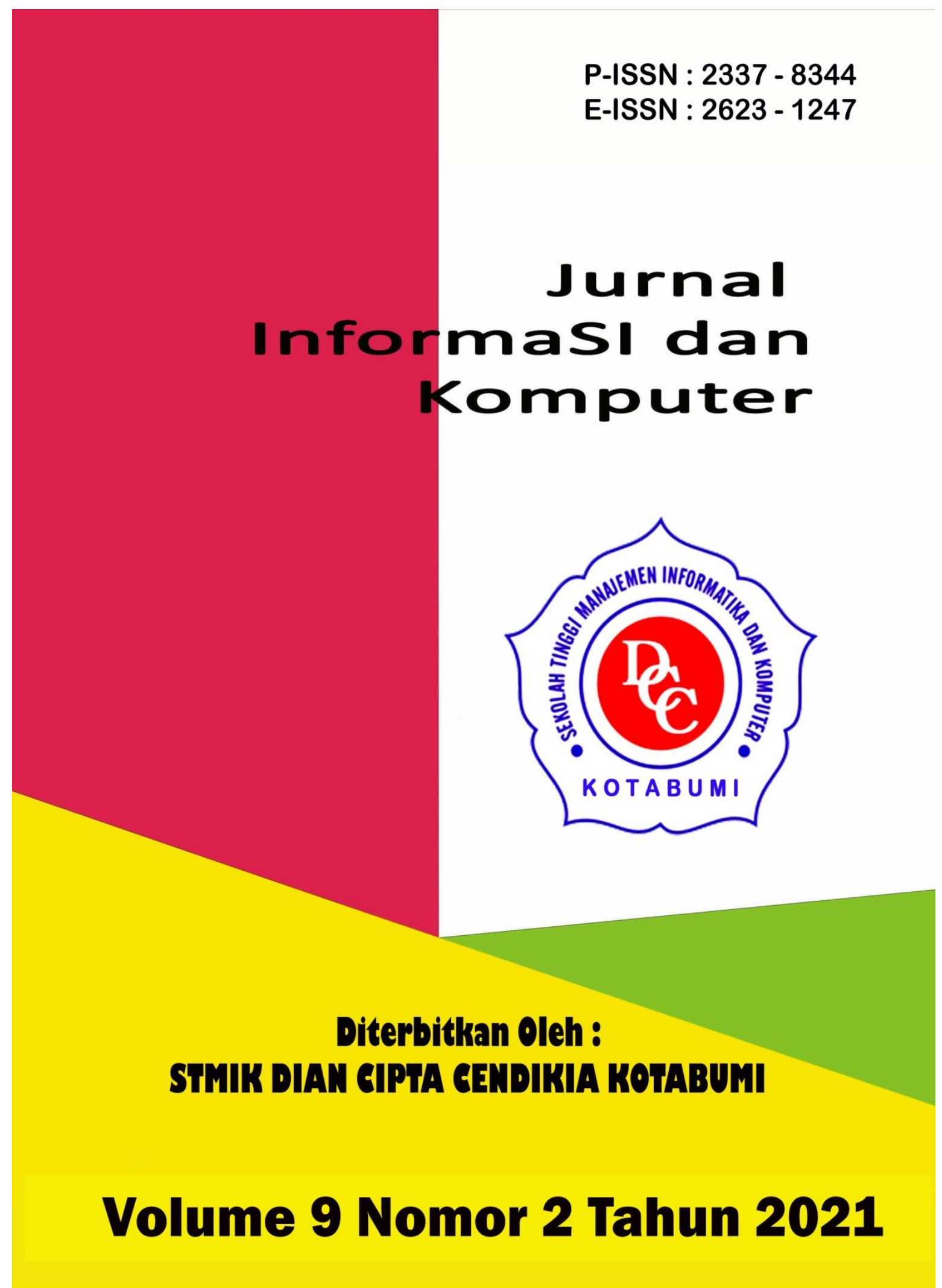


Penerbit

Lembaga Penelitian STMIK Dian Cipta Cendikia Kotabumi

Hak atas naskahh/tulisan tetap berada pada penulis, isi diluar tangung jawab penerbit dan Dewan Penyunting

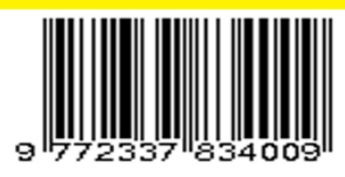




\section{PENGANTAR REDAKSI}

Puji syukur dipanjatkan kehadirat Tuhan Yang Maha Esa, atas karunia dan limpahan rahmatNYA jualah Jurnal Informasi dan komputer (JIK) STMIK Dian Cipta Cendikia Kotabumi ini dapat terwujud.Jurnal Informasi dan Komputer (JIK) yang terbit dua (2) kali dalam setahun ini merupakan suatu wadah untuk penyebar luasan hasil-hasil penelitian, studi pustaka, karya ilmiah yang berkaitan dengan Informasi dan Komputer khususnya bagi dosen-dosen STMIK Dian Cipta Cendikia Kotabumi serta umumnya para cendikiawan, praktisi, peneliti ilmu Informatika dan Komputer.

Harapan, dengan diterbitkannya Jurnal Informasi dan Komputer (JIK) ini sebagai salah satu bentuk sumbangan pemikiran dalam pengembangan ilmu informatika dan komputer yang berkaitan dengan kajian-kajian di bidang tekhnologi Informatik, Komunikasi Data dan Jaringan Komputer, perancangan dan Rekayasa Perangkat Lunak, serta ilmu-ilmu yang terkait dengan bidang Informasi dan Komputer lainnya.

Berkenaan dengan harapan tersebut, kepada para peneliti, dosen dan praktisi yang memiliki hasil-hasil penelitian, kajian pustaka, karya ilmiah dalam bidang tersebut diatas, dengan bangga redaksi Jurnal Informasi dan Komputer (JIK) menerima naskah ringkasan untuk dimuat pada jurnal Informasi dan Komputer (JIK) STMIK Dian Cipta Cendikia Kotabumi dengan berpedoman pada penulisan naskah jurnal sebagaimana dilampirkan pada halaman belakang (Bagian kulit dalam) buku jurnal ini.

Mutu dari suatu jurnal ilmiah tidak hanya ditentukan oleh para pengelolanya saja, tetapi para penulis dan pembaca jualah yang mempunyai peranan besar dalam meningkatkan mutu jurnal Informatika dan Komputer ini. Merujuk pada realita ini kamu sangat mengharapkan peran aktif dari peneliti untuk bersama-sama menjaga dan memelihara keberlangsungan dari jurnal Informasi dan Komputer STMIK Dian Cipta Cendikia Kotabumi ini. Yang juga tidak kalah pentingnya dari partisipasi tersebut diatas, adalah saran dan kritik yang membangun dari pembaca yang budiman agar kiranya dapat disampaikan langsung kepada redaksi JIK. Saran dan kritik yang membangun akan dijadikan masukan dan pertimbangan yang sangat berarti guna peningkatan mutu dan kualitas Jurnal Informasi dan Komputer STMIK Dian Cipta Cendikia Kotabumi.

Tak lupa diucapkan terima kasih yang tak terhingga atas perhatian dan kerjasama dari semua pihak yang tak dapat disebutkan satu persatu hingga dapat diterbitkan nya Jurnal Informasi dan Komputer (JIK) STMIK Dian Cipta Cendikia Kotabumi. Semoga apa yang telah diperbuat untuk kebaikan akan menjadi amal ibadah, amin.

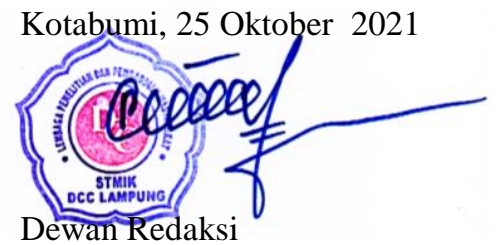




\section{JURNAL INFORMASI DAN KOMPUTER}

Volume 9 Nomor 2 Oktober 2021

Jurnal Informasi dan Komputer merupakan Sarana informasi ilmu pengetahuan, Tekhnologi dan Komunikasi yang berupa hasil penelitian, tulisan ilmiah, Ataupun studi pustaka. Jurnal ini terbit dua kali setahun pada bulan April dan Oktober. Berisi hasil penelitian ilmiah di bidang informatika yang bertujuan untuk menghubungkan adanya kesenjangan antar kemajuan teknologi dan hasil penelitian. Jurnal ini di terbitkan pertama kali pada tahun 2013.

Penanggung Jawab:

Ketua STMIK Dian Cipta Cendikia Kotabumi

\section{Pembina:}

Ketua STMIK Dian Cipta Cendikia Kotabumi Ketua Lembaga Penelitian STMIK Dian Cipta Cendikia Kotabumi

\section{Pimpinan Redaksi}

Dwi Marisa Efendi,.S.Kom.,M.Ti

\section{Redaksi pelaksana}

Rustam,.S.Kom,.M.Ti (STMIK Dian Cipta Cendikia Kotabumi)

Nurmayanti M.Kom (STMIK Dian Cipta Cendikia Kotabumi)

Sukatmi,.S.Kom., M.Kom (AMIK DCC Bandar Lampung)

Sampurna Dadi Riskiono,M.Kom (Universitas Teknokrat Indonesia)

Ifo Wahyu Pratama,S.Kom.,M.Ti(AMIK MASTER Lampung)

\section{Mitra Bestari}

Dr. RZ. ABDUL AZIZ, ST., MT (Institut Informatika dan Bisnis Darmajaya)

Dr. Dadang Sudrajat, S.Si, M.Kom (STMIK IKMI Cirebon)

Dr. Septafiansyah Dwi Putra, S.T., M.T (Politeknik Negeri Lampung)

Dr. Evi Grativiani, S.E., M.S.I (Universitas Sebelas Maret)

Rohmat Indra Borman ( Universitas Teknokrat Indonesia )

Ferry Wongso, S.KOm., M.Kom ( STMIK Darma Pala Riau)

Ferly Ardhy, S.Kom., M.Ti ( Universitas Aisyah Pringsewu )

Firmansyah, S.E., M.Si (STMIK Darma Pala Riau)
Amarudin (Universitas Teknokrat Indonesia)

Didi Susianto, S.T., M.Kom (AMIK Dian Cipta Cendika Bandar Lampung)

Alhibarsyah, St., M.Kom (STMIK Tunas

Bangsa Bandar Lampung)

Kemal Farouq Mauladi, S.Kom .M.Kom (Universitas Islam Lamongan)

Rima Mawarni, M.Kom ( STMIK Dian Cipta Cendikia Kotabumi)

Wira Jaya Hartono, S.Pd., M.Pd ( STMIK Darma Pala Riau)

Penerbit : STMIK Dian Cipta Cendikia Kotabumi Bekerja Sama Dengan LPPM STMIK Dian Cipta Cendikia Kotabumi.

\section{Alamat Redaksi/Penerbit:}

Jl. Negara No. 3 Candimas Kotabumi Lampung Utara

No Telpon/Fax 072423003

Email : 1ppm-stmik@dcc.ac.id 


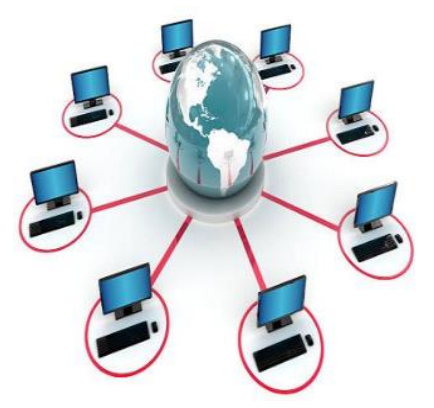

\section{JURNAL INFORMASI DAN KOMPUTER VOL. 9 NO. 2 THN. 2021}

\section{DAFTAR ISI}

Halaman

Sistem Informasi Akuntansi Persedian Barang Berbasis Web Pada Lembaga

Permasyarakatan Kelas II A Banceuy Bandung : "Kelompok Tani Desa Banjar Kertarahayu” Teuku Rian Hardiyansyah, Fatia Salsa Azzahra (Politeknik Piksi Ganesha Bandung ${ }^{1,2}$ ).

Penerapan Finite State Automata Pada Vending Machine Penjual Obat Non Resep

Dokter Dan Keperluan Medis

Eko Supriyanto $^{1}$, Angga Ardiansyah ${ }^{2}$, Frieyadie $^{3}$, Sri Rahayu ${ }^{4}$, Windu Gata ${ }^{5}$

(Universitas Nusa Mandiri ${ }^{12}$ )

Sistem Pendukung Keputusan Untuk Menentukan Kelayakan Pengajuan Sertifikasi Guru Dengan Metode Simple Additive Weighting (Studi Kasus : Ma Al Muhajirin Janti Jogoroto Jombang)

Budiman, umam baharudin, winarti

(Universitas Darul ‘Ulum Jombang)

1.

2. Perancangan Infrastruktur Domain Name Server Lokal Menggunakan Ubuntu Server 16.04

3. Pada PT. Xyz

Zaenal Mutaqin Subekti, Hendra Setiawan, Satria, Widia Murni Wijaya,

Aliy Hafiz, Warsudi

(STMIK Bani Saleh, Universitas Negeri Yogyakarta, AMIK Dian Cipta Cendikia,

STMIK MIC CIkarang)

Perancangan Sistem Informasi Idea Proposal (Ip) Berbasis Web Pada Pt. Paxel Algorita Unggul

Julian Murhan Sahputra, Indah Purnamasari

(Universitas Nusa Mandiri ${ }^{12}$ )

Sistem Pendukung Keputusan Untuk Menentukan Ekstrakurikuler Atletik

Berdasarkan Bakat Siswa Menggunakan Metode Profile Matching

Agnes Basuki, Petrus Sokibi, Tiara Eka Putri

(Universitas Catur Insan Cendekia)

Penerapan Algoritma K-Means Untuk Pengelompokan Usia Calon Penerima Vaksin

Di Kab. Ngawi

Irna Yuniarfi, Saifulloh

(Universitas PGRI Madiun ${ }^{12}$ )

System Penilaian Seleksi Calon Karyawan Baru Menggunakan Metode Simple Additive Weighting (SAW) Di PT.TNA

Anik Sri Wahyuningsih, Yudhi Firmansyah

(Universitas Panca Sakti Bekasi ) 
Perancangan Sistem Informasi Pembayaran SPP Menggunakan Framework Laravel Ichwan Habib Moudi

(Universitas Panca Sakti Bekasi)

Implementasi Algoritma K-Means Dan Algoritma Apriori Optimasi Kinerja Ecu

(Study Kasus Mobil Avanza Dan Xenia)

Sigit Mintoro' Asep Afandi

(STMIK Dian Cipta Cendikia Kotabumi)

Sistem Pakar Penyakit Buah Kakao Untuk Peningkatan Hasil Panen Kakao Menggunakan

Metode Case Base Reasoning (CBR) Berbasis Web Mobile

Aliy hafiz, Verawati

(AMIK Dian Cipta Cendikia,Bandar Lampung)

Penerapan Metode Rapid Application Develomment (RAD) Dalam Pengembangan

Sistem Pemesanan Menu Berbasis Android

Aris Baihaqi, Tumini

(Fakultas Sains dan Teknologi ${ }^{1,2}$ )

Rancang Bangun Sistem Informasi Geografis Pariwisata Di Lampung Timur

Sukatmi, Rexa Alfa Rizi

(AMIK DCC Bandar Lampung ${ }^{12}$ )

Implementasi Psak No. 45 Pada Proses Penyusunan Laporan Keuangan Menggunakan

M.S. Excel Dan Aplikasi Accurate Accouting Pada STMIK Bani Saleh

Marhakim, Willy Adam

(STMIK Bani Saleh ${ }^{12}$ )

Sistem Prediksi Harga KOPI LAMBAR ( Lampung Barat) Dengan Metode

Backpropagation, dan Double Exponential ( Studi Kasus BUMDES )

Supriyanto, Dwi marisa Efendi,Rhomadhon

(STMIK Dian Cipta cendikia Kotabumi ${ }^{1-}$ )

Sistem Informasi Pemasaran Produk Umkm Berbasis Web Pada Kecamatan Bumi

Nabung Lampung Tengah

Yuli Syafitri, Agus Prasetyo, Reni Astika

(AMIK Dian Cipta Cendikia Bandar Lampung)

Rancang Bangun Aplikasi Pembelajaran Aksara Lampung Berbasis Android

Ferly Ardhy, Hendra Syahrobi

(Universitas Aisyah Pringewu ${ }^{1,}$ STMIK Dian Cipta Cendikia ${ }^{2}$ )

Sistem Pakar Diagnosa Penyakit Kulit Pada Balita Menggunakan Metode Naïve

Bayes Dan Forward Chaining Studi Kasus Puskesmas Cempaka Sungkai Selatan

Sidik Rahmatullah, Rima Mawarni

(STMIK Dian Cipta Cendikia Kotabumi ${ }^{12}$ )

Rekayasa Perangkat Lunak Perhitungan Harga Pokok Produksi Metode

Full Costing Pada Umkm Mitra Cake Di Bandar Lampung

Pitrawati, Arif Sanjaya

(AMIK Dian Cipta Cendikia, Bandar Lampung) 
4. Rancang Bangun Sistem Ujian Online Menggunakan Algoritma Cosine Similarity

5. Berbasis Web

Haryono, Zaenal Mutaqin Subekti, Widiyawati, Hidayatullah

(STMIK Bani Saleh ${ }^{1234}$ )

Model Aplikasi Helpdesk Ticketing System Berbasis Web Menggunakan Metode Rad

Indra Permana

Pattern Recognition Tulisan Tangan Huruf Hijaiyah Menggunakan Metode

Convolutional Neural Network (CNN)

Mufassiril Abror, Nopiyanto

(Universitas Panca Sakti Bekasi ${ }^{12}$ )

Aplikasi Sistem Informasi Keuangan Berbasis Android Di Perumahan Taman

Karang Bahagia

Melda Ayulestari

(Universitas Panca Sakti Bekasi)

6. Audit Pelayanan Sistem Rujukan Online Puskesmas Menggunakan Framework COBIT 5.0

Nurmayanti, Merri Parida, Ngajiyanto, Ina Anzalna

(STMIK Dian Cipta Cendikia Kotabumi ${ }^{1234}$ )

Perancangan Sistem Informasi Pengolahan Data Nilai Siswa Berbasis Web

Erin Ermawati, Anik Sri Wahyuningsih

(Fakultas Sain dan Teknologi, Universitas Panca Sakti Bekasi ${ }^{12}$ )

Pengembangan Sistem Pelaporan Data Hasil Inspeksi Barang Berbasis Web

Siska Putriani

(Universitas Pancasakti Bekasi)

Penerapan Extreme Programming Dalam Perancangan Aplikasi Web Food Market

Tumini, Hilman Septiana

(Fakultas Sains dan Teknologi Universitas Panca Sakti Bekasi ${ }^{1,2}$ )

Sistem Pencarian Barang Berbasis Website Menggunakan Php Dan Mysql

Studi Kasus PT. Surya Technology Industri Sulaeman

(Universitas Panca Sakti Bekasi)

Implementasi Metode Prototype Pada Sistem Peminjaman Alat Kerja Berbasis Web

Di PT SK Metalindo

Ali Mulyanto, Arjun Gunawan

(Univeritas Panca Sakti Bekasi)

Aplikasi Tata Cara Wudhu Menggunakan Teknologi Augmented Reality

Sebagai Media Pembelajaran Di TK Al Fatih

Ahmad Yakub , Idarul Fadli

(Universitas Panca Sakti Bekasi ${ }^{12}$ )

Sistem Pakar Diagnosa Penyakit Ayam Petelur Menggunakan Metode Certainty Factor

Berbasis Web Mochammad

Taufiq Hidayat, Ali Mulyanto

(Universitas Panca Sakti Bekasi ${ }^{12}$ ) 
Penerapan Metode Prototyping Dalam Perhitungan Hasil Produksi Menggunakan

Arduino Uno R3 Dan Php Di PT. Indonesia Epson Industry

Amandha Aulia, Ajar Rohmanu

(Universitas Panca Sakti Bekasi ${ }^{12}$ )

System Pendukung Keputusan Penentuan Guru Teladan Dengan Metode Profile Matching

Hasbulloh, Agmawarnida

(Universitas Panca Sakti Bekasi ${ }^{1,2}$ )

Implementasi Waterfall Method Pada Aplikasi Buku Induk Siswa Berbasis Web

Idam Holid, Yogie Krisnayadi

(Universitas Panca Sakti ${ }^{12}$ )

Pengembangan Text To Speech Media Pembelajaran Untuk Pengenalan

Anggota Tubuh Manusia Kelas V Sekolah Dasar

Juwanda Saputra, Ali Mulianto

(Teknik Infomratika Fakulutas Sains dan Teknologi ${ }^{12}$ )

Perancangan Sistem Peminjaman Barang Berupa Aset Tetap Berbasis Web

Pada Lembaga Permasyarakatan Kelas II A Banceuy Bandung

Guntur Salasa Priambodo, Perwito, Candra Mecca Sufyana

(Politeknik Piksi Ganesha Bandung ${ }^{1,2,3}$ )

Metode Pemilihan Karyawan Terbaik Sebagai Penentu Goodwill Perguruan Tinggi

Dengan Menggunakan Metode Topsis (Studi Kasus Perguruan Tinggi Di Lampung Utara)

Dwi Sartika, Pakarti Riswanto

(STMIK Dian Cipta Cendikia Kotabumi)

Sistem Pendukung Keputusan Pemilihan Merek Smartphone Menggunakan

Metode Analytical Hierarchy Process (AHP)

Ade Kiki Fatmawati, Muhammad Sultan Raflie, Norma Yunita

(Universitas Nusa Mandiri ${ }^{123}$ )

Pattern Recognition Aksara Lampung Menggunakan Algoritma Neural Network

Metode Analytical Hierarchy Process (AHP)

Nopiyanto, Rahmadi

(Universitas Panca Sakti Bekasi) 


\title{
SISTEM PAKAR DIAGNOSA PENYAKIT KULIT PADA BALITA MENGGUNAKAN METODE NAÏVE BAYES DAN FORWARD CHAINING STUDI KASUS PUSKESMAS CEMPAKA SUNGKAI SELATAN
}

\author{
Sidik Rahmatullah $^{1}$, Rima Mawarni ${ }^{2}$ \\ STMIK Dian Cipta Cendikia Kotabumi ${ }^{12}$ \\ J1.Negara Nomor 03 Candimas Kotabumi Lampung Utara ${ }^{12}$ \\ E-mail: sidik@dcc.ac.id ${ }^{1}$,rima@dcc.ac.id ${ }^{2}$
}

\begin{abstract}
ABSTRAK
Pusat Kesehatan Masyarakat (Puskesmas) merupakan kesatuan organisasi fungsional yang menyelenggarakan upaya kesehatan yang bersifat menyeluruh, terpadu, merata dapat diterima dan terjangkau oleh masyarakat. Tujuan penelitian ini adalah membuat Aplikasi Sistem Pakar untuk mendeteksi penyakit kulit pada balita sesuai dengan data-data yang ada pada Puskesmas. Metode pengembangan sistem yang digunakan yaitu metode Extreme Programing (XP) dengan tahapan pengerjaan meliputi planning, design, coding dan testing. Sistem dirancang dengan menggunakan Unified Modeling Language (UML) yang meliputi use case, activity diagram, dan class diagram, perangkat lunak yang digunakan adalah PHP (Hypertext Preprocessor) dengan database MySQL dan menggunakan metode Naïve Bayes dan Forward Chaining. Hasil akhir dari pembuatan Aplikasi ini adalah memudahkan pasien, dokter dan bidan mendeteksi penyakit kulit pada balita di Puskesmas.
\end{abstract}

Kata Kunci : Sistem Pakar, Extreme Programing, Nä̈ve Bayes, Forward Chaining.

\begin{abstract}
The Community Health Center (Puskesmas) is a functional organizational unit that organizes comprehensive, integrated, equitable health efforts that are acceptable and affordable to the community. The purpose of this study was to make an Expert System Application to detect skin diseases in infants according to the data available at the Health Center. The system development method used is the Extreme Programing $(X P)$ method with the stages of work including planning, design, coding and testing. The system is designed using Unified Modeling Language (UML) which includes use cases, activity diagrams, and class diagrams, the software used is PHP (Hypertext Preprocessor) with MySQL databases and using the Nä̈ve Bayes and Forward Chaining methods. The final result of making this application is to make it easier for patients, doctors and midwives to detect skin diseases in toddlers at Health Center.
\end{abstract}

Keywords: Expert System, Extreme Programing, Naïve Bayes, Forward Chaining Method

\section{PENDAHULUAN}

Kulit adalah salah satu bagian tubuh manusia yang penting di samping sebagai keindahan tubuh manusia, juga salah satu fungsinya mengatur suhu tubuh manusia, demi melindungi dan menjaga tubuh dari berbagai macam penyakit. Karakteritik dari kulit yang elastis dan tipis menyebabkan rentan terserang penyakit jika tidak menjaga Kesehatan kulit. Kesehatan merupakan hal yang berharga bagi manusia, karena siapa saja dapat megalami gangguan kesehatan. Termasuk anak yang dibawah umur lima tahun sangat rentan terhadap kuman penyakit dan kurangnya kepekaan terhadap gejala suatu penyakit, apabila terjadi gangguan kesehatan terhadap anak maka mereka lebih mempercayakannya kepada pakar atau dokter ahli yang sudah mengetahui lebih banyak tentang kesehatan, tanpa memperdulikan apakah gangguan tersebut masih dalam tingkat rendah atau kronis. Namun dengan kemudahan adanya para pakar atau dokter ahli, terkadang terdapat pula kelemahannya seperti jam kerja (praktek) terbatas dan banyaknya pasien hingga harus menunggu antrian yang panjang dengan biaya yang tidak sedikit.[1] 
Penyakit pada balita menjadi ketakutan besar bagi orang tua, tubuh balita yang rentan terhadap penyakit menjadi salah satu faktor penyebabnya. Dalam hal ini, orang tua selaku pemakai jasa lebih membutuhkan seorang pakar yang bisa memudahkan dalam mendiagnosa penyakit lebih dini agar dapat melakukan pencegahan lebih awal yang sekiranya membutuhkan waktu lama jika berkonsultasi dengan dokter ahli, biaya dan jarak tempuh. Karena hal tersebutlah maka dibutuhkan suatu alat bantu yang dapat mendiagnosa penyakit kulit pada balita berupa sistem. Salah satu implementasi yang diterapkan sistem pakar dalam bidang kesehatan anak, yaitu sistem pakar untuk mendiagnosa penyakit kulit pada balita[1]

Adapun tujuan dari penelitian ini adalah untuk membantu masyarakat dalam mendeteksi awal penyakit kulit pada balita dan memberikan saran dalam pengobatan yang mungkin dilakukan. Memberikan pengetahuan kepada masyarakat tentang beberapa penyakit kulit yang biasa di derita balita. dengan menggunakan metode Forward Chaining, bahwa aplikasi sistem pakar ini dapat mendiagnosa suatu penyakit anak (balita) yang sering diderita berdasarkan gejala yang dialami, kemudian dapat memberikan informasi penyakit tersebut beserta solusinya. Dengan diberikan interface yang user friendly maka aplikasi sistem pakar ini dapat mudah dipelajari dan mudah digunakan untuk kalangan orang awam, sehingga dapat mempermudah dalam mendiagnosa penyakit".

Selanjtunya penelitian yang dilakukan oleh "pengembangan Sistem Pakar Untuk Diagnosa Penyakit Kulit Pada Manusia Menggunakan Metode naïve Bayes, pada penelitian ini bagaimana mengembangkan suatu system pakar untuk diagnose penyakit kulit, menggunakan Bahasa pemrograman java dengan hasil implementasi didapatkan data terdiri dari 366 kasus gejala dan 6 jenis penyakit kulit sehingga kesimpulannya adalah system yang dikembangkan menjadi sebuah pengembangan system pakar untuk diagnose penyakit kulit pada manusia menggunakan metode naïve bayes dengan nilai akurasi sebesar 92\%”[2].
Selanjutnya penelitian yang dilakukan oleh [3] yang mengambil judul "Aplikasi Sistem Pakar Untuk Mendiagnosa Penyakit Anak (balita) dengan menggunakan metode Forward Chaining, bahwa aplikasi sistem pakar ini dapat mendiagnosa suatu penyakit anak (balita) yang sering diderita berdasarkan gejala yang dialami, kemudian dapat memberikan informasi penyakit tersebut beserta solusinya. Dengan diberikan interface yang user friendly maka aplikasi sistem pakar ini dapat mudah dipelajari dan mudah digunakan untuk kalangan orang awam, sehingga dapat mempermudah dalam mendiagnosa penyakit".

Penelitian dengan judul Sistem Pakar Diagnosa Penyakit Kulit Menggunakan Metode Forward Chaining, [4] Aplikasi system pakar ini mampu meniru kerja seorang pakar dalam berbagai bidang, salah satunya mendiagnosa penyakit kulit.aplikasi pakar ini menggunakan metode forward chaining dan dirancang dengan menggunakan Bahasa pemrograman php dan mysql. Dengan adanya aplikasi system pakar diagnose penyakit kulit dapat membantu seseorang Terutama dikalangan masyarakat untuk mengetahui penyakit kulit yang dialami serta Untuk mengetahui pertolongan utama yang harus dilakukan. Dapat memberikan pengetahuan akan penyakit kulit yang dialami user.

Metode Naïve Bayes adalah sebuah Teknik klasifikasi probabilistik yang berdasarkan teorema bayes yang menggunakan asumsi keindenpendenan atribut (tidak ada kaitan antar atribut) dalam proses pengkla.sifikasiannya. Naïve bayes dapat dilatih dengan efisien dalam pembelajaran terawasi (supervised learning). Keuntungan dari klasifikasi adalah bahwa ia hanya membutuhkan sejumlah kecil data pelatihan (training) untuk memperkirakan parameter (sarana dan varian dari variabel) yang diperlukan untuk klasifikasi. Karena variabel independen di asumsikan, hanya variasi dari variabel untuk masing-masing kelas harus ditentukan, bukan seluruh matriks kovarians. Dalam prosesnya, Naïve Bayes Classifier mengasumsikan bahwa ada atau tidaknya suatu fitur pada suatu kelas tidak berhubungan dengan ada atau tidaknya fitur lain dikelas yang sama.[5]

Berikut perhitungan dalam metode naïve bayes dengan persamaan teorema bayes [5] adalah sebagai berikut: 
$\mathrm{P}(\mathrm{B} \mid \mathrm{A})=\mathrm{P} \frac{(\mathrm{A} \mid \mathrm{B}) \mathrm{P}(\mathrm{B})}{\mathrm{P}(\mathrm{A})}$

(1)

Dimana:

$\mathrm{P}(\mathrm{B} \mid \mathrm{A})=$ Peluang $\mathrm{B}$ jika diketahui keadaan jenis penyakit A.

$\mathrm{P}(\mathrm{B} \mid \mathrm{A})=$ Peluang evidence $\mathrm{A}$ jika diketahui hipotesis B.

$\mathrm{P}(\mathrm{B})=$ Probabilitas hipotesis $\mathrm{B}$ tanpa memandang evidence apapun.

$\mathrm{P}(\mathrm{A}) \quad=$ Peluang evidence penyakit $\mathrm{A}$.

Persamaan dapat ditulis menggunakan teorema Bayes sebagai berikut.

Vmap $=\operatorname{argmax} \epsilon$

v P (vj|a1, a2, a3 ... an|vj)P(vj)

Metode ForwardChaining adalah "teknik pencarian yang dimulai dengan fakta yang diketahui, kemudian mencocokkan fakta tersebut dengan bagian IF dari rules IF-THEN. Bila ada fakta yang cocok dengan bagian IF, maka rule tersebut dieksekusi. Bila sebuah rule dieksekusi, maka sebuah fakta baru (bagian THEN) ditambahkan ke dalam database. Setiap kali pencocokan, dimulai dari rule teratas. Setiap rule hanya boleh dieksekusi sekali saja.[6]Proses pencocokan berhenti bila tidak ada lagi rule yang bisa dieksekusi”.

\section{METODE PENELITIAN}

\subsection{Teknik Pengumpulan Data}

\section{Wawancara}

Melakukan tanya jawab pada pihak yang berkepentingan di dalam bidangnya agar penelitian yang dilakukan sesuai dengan masalah yang terjadi serta mengumpulkan information yang dibutuhkan untuk menyelesaikan suatu permasalahan yang sering terjadi dalam penyakit kulit balita pada Puskesmas.

\section{Observasi}

Suatu Teknik bagaimana penulis datang langsung ke tempat penelitian untuk membuat catatan efisien tentang perilaku dengan melihat atau memperhatikan objek secara langsung.

\section{Studi Pustaka}

Penulis mengumpulkan data dengan cara mencari referensi-referensi dari buku-buku serta jurnal-jurnal untuk membantu dalam mengumpulkan informasi serta dapat menjadi bahan acuan dalam penyelesaian penelitian ini.

\subsection{Metode Extreme Programming}

Penelitian ini menggunakan metode pengembangan yaitu Extreme Programming.[7]

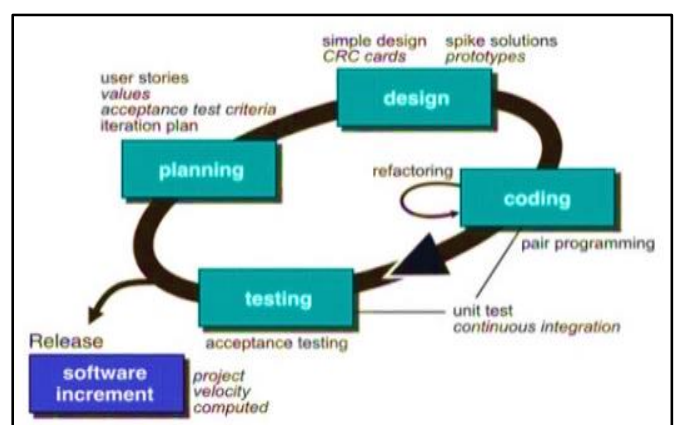

Gambar 1. Metode Extreme Programming[7]

\section{Planning}

Planning berfokus untuk mendapatkan gambaran fitur dan fungsi dari perangkat lunak yang akan dibangun. Aktivitas planning dimulai dengan membuat kumpulan gambaran atau cerita yang telah diberikan oleh klien yang akan menjadi gambaran dasar dari perangkat lunak tersebut.

\section{Design}

Aktivitas design dalam pengembangan aplikasi ini, bertujuan untuk mengatur pola logika dalam sistem. Sebuah desain aplikasi yang baik adalah desain yang dapat mengurangi ketergantungan antar setiap proses pada sebuah sistem.

\section{Coding}

Setelah menyelesaikan gambaran dasar perangkat lunak dan menyelesaikan design untuk aplikasi secara keseluruhan, XP lebih merekomendasikan tim untuk membuat modul unit tes terlebih dahulu yang bertujuan untuk melakukan uji coba setiap cerita dan gambaran yang diberikan oleh klien. Setelah berbagai unit tes selesai dibangun, tim barulah melanjutkan aktivitasnya ke penulisan coding aplikasi..

\section{Testing}


Walaupun tahapan uji coba sudah dilakukan pada tahapan coding, XP juga akan melakukan pengujian sistem yang sudah sempurna. Pada tahap coding, XP akan terus mengecek dan memperbaiki semua masalah-masalah yang terjadi walaupun hanya masalah kecil. Setiap modul yang sedang dikembangkan, akan diuji terlebih dahulu dengan modul unit tes yang telah dibuat sebelumnya

2.2.1 Diagram Alir metode naïve bayes Berikut ini adalah diagram alir metode naïve bayes seperti yang tertera pada gambar 2

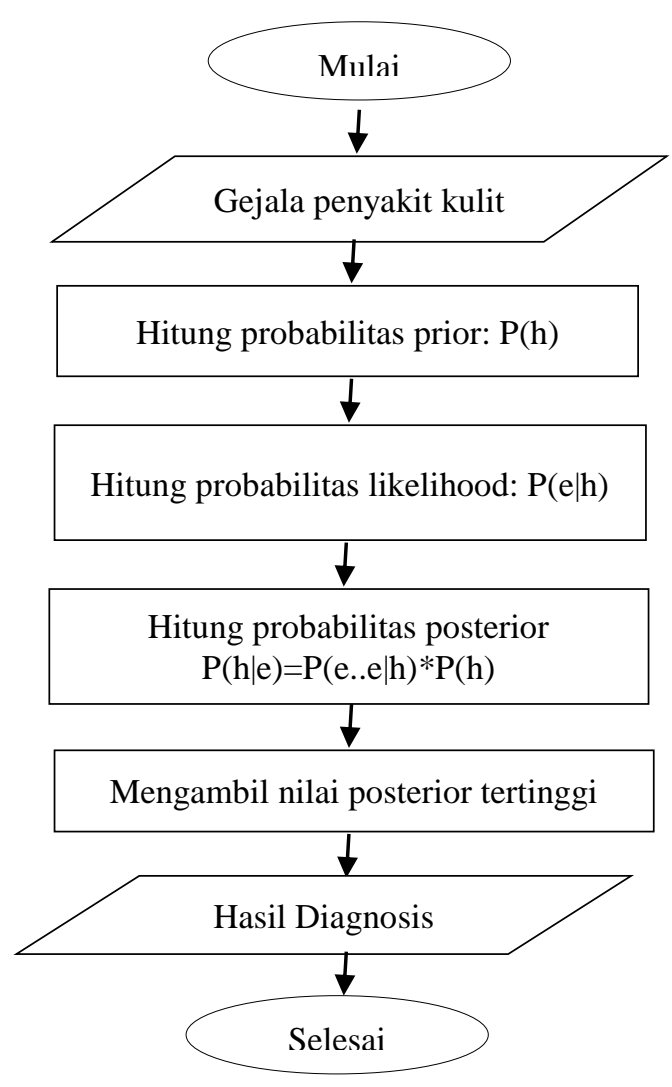

Gambar 2. Diagram alir naïve bayes

\subsection{2 diagram alir Forward chaining}

Berikut ini adalah diagram Forward chaining secara umum dalam menyelesaikan suatu masalah[8]

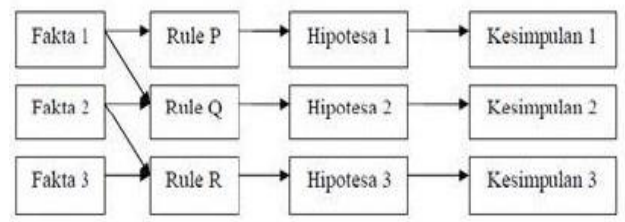

Gambar 3 diagram Forward Chaining

\subsection{Analisa Data}

Pada Analisa data digambarkan sistem lama dan syitem yang akan dibangun yaitu :

1. System lama yaitu menggambarkan system yang sedang digunakan atau system yang sedang berjalan yaitu

a. Pasien datang dan langsung berkonsultasi dengan pakar atau dokter umum Pasien datang langsung ke pakar atau dokter anak.

b. Pendaftaran akan ditulis nama pasien, jenis kelamin, alamat dan lain-lainnya.

c. Pasien menungu antrian jika terdapat antrian.

d. Pakar atau dokter kulit akan bertanya langsung kepada pasien atau orang tua pasien apa saja keluhan atau ciri-ciri penyakit kulit yang diderita.

e. Pakar atau dokter akan memberikan selembaran kertas yang berisikan penyakit, gejala, dan solusi obat yang harus dibeli.

2. Gambaran Umum Sistem yang di bangun Gambaran umum sistem yang sedang dibangun/dirancang

a. Pasien membuka halaman web atau masuk kehalaman web kemudian klik menu diagnosa.

b. Pasien akan mengisi data diri kemudian klik diagnosa untuk melanjutkan.

c. Pasien akan diberikan beberapa pertanyaan yang ditampilkan berupa jawaban ya atau tidak.

d. Pasien dapat melihat informasi dari daftar penyakit kulit anak balita beserta penjelasannya .

e. Pasien akan diberi info dari hasil jawaban yang telah diisi jawaban dari diagnosa tadi berupa gejala, penyakit yang diderita dan solusi dari penyakit tersebut.

f. Pasien dapat keluar jika sudah selesai didiagnosa.

Gambaran umum Sistem Pakar Diagnosa Penyakit Kulit Pada Balita:

a. Munculnya sistem pakar diagnose penyakit kulit pada balita membantu pakar bekerja lebih efisien, efektif dan dapat menangani pasien untuk berkonsultasi secara digital. 
b. Pengaksesan data dan informasi penyimpanan data diagnosa pasien menggunakan database MySQL.

c. Pasien dapat konsultasi dimana saja tanpa antri ke dokter kulit atau pakar.

\subsection{Tahapan Penelitian}

\section{Basis Pengetahuan Penyakit Kulit}

Berikut adalah data penyakit kulit pada balita beserta kodenya masing-masing dapat dilihat pada tabel berikut :

Tabel 1. Basis Pengetahuan Penyakit Kulit

\begin{tabular}{|l|l|}
\hline ID_Penyakit & \multicolumn{1}{|c|}{ Penyakit } \\
\hline P01 & Kerak kepala bayi (cradle cap $)$ \\
\hline P02 & Kulit merah dan gatal ( eksim $)$ \\
\hline P03 & Campak \\
\hline P04 & Kutil \\
\hline P05 & Cacar air \\
\hline P06 & Biang Keringat \\
\hline P07 & Ruam popok \\
\hline
\end{tabular}

\section{Basis Pengetahuan Gejala Penyakit Kulit}

Gejala dari penyakit kulit beserta kodenya masing-masing dapat dilihat pada tabel berikut

Tabel 2. Basis Pengetahuan Gejala Penyakit Kulit

\begin{tabular}{|c|l|}
\hline $\begin{array}{c}\text { ID_Gej } \\
\text { ala }\end{array}$ & Gejala \\
\hline G01 & Kemerahan ringan pada kulit \\
\hline G02 & Rasa gatal berlebihan pada kulit \\
\hline G03 & $\begin{array}{l}\text { Kulit berminyak atau kering yang } \\
\text { tertutupi sisik berwarna putih, } \\
\text { kuning tau bewarna gelap }\end{array}$ \\
\hline G04 & $\begin{array}{l}\text { Hormon dari ibu pindah pada bayi } \\
\text { pada saat kehamilan }\end{array}$ \\
\hline G05 & $\begin{array}{l}\text { Kulit alergi terhadap lingkungan yang } \\
\text { kurang bersih }\end{array}$ \\
\hline G06 & Kulit alergi terhadap makanan \\
\hline G07 & Kulit memerah \\
\hline G08 & Kulit bersisik serta pecah-pecah \\
\hline G09 & $\begin{array}{l}\text { Kulit timbul gelembung- } \\
\text { gelembung kecil yang } \\
\text { mengandung air atau nanah }\end{array}$ \\
\hline G10 & $\begin{array}{l}\text { Kulit alergi zat kimia seperti } \\
\text { detergen, sabun, dan obat-obatan }\end{array}$ \\
\hline G11 & Kulit alergi serbuk sari tanaman \\
\hline G12 & Kulit alergi terhadap debu dan iklim \\
\hline
\end{tabular}

\begin{tabular}{|l|l|}
\hline G13 & $\begin{array}{l}\text { Demam tinggi 4 hari sebelum } \\
\text { ruam muncul }\end{array}$ \\
\hline G14 & Mata balita memerah \\
\hline G15 & Batuk dan pilek \\
\hline G16 & $\begin{array}{l}\text { Bintik-bintik putih tampak di } \\
\text { sepanjang garis mulut }\end{array}$ \\
\hline G17 & $\begin{array}{l}\text { Terkena kontak dengan anak } \\
\text { penderita campak lainnya }\end{array}$ \\
\hline G18 & Sulit untuk makan \\
\hline G19 & $\begin{array}{l}\text { Linglung atau terus menerus } \\
\text { mengigau }\end{array}$ \\
\hline G20 & Sakit kepala parah \\
\hline G21 & Mengeluhkan sakit telinga \\
\hline G22 & Muncul benjolan kecil pada kulit \\
\hline G23 & Rasa gatal berlebihan pada kulit \\
\hline G24 & Sakit bila disentuh pada benjolan \\
\hline G25 & Gangguan tenggorokan \\
\hline G26 & $\begin{array}{l}\text { Tubuh anak melemah dan tidak } \\
\text { merasa lapar }\end{array}$ \\
\hline G27 & Muncul bintik-bintik merah \\
\hline G28 & $\begin{array}{l}\text { Bintik merah akan memenas lalu } \\
\text { pecah dan mengeluarkan air }\end{array}$ \\
\hline G29 & Pembengkakan ringan \\
\hline G30 & Kulit terasa perih dan tertusuk-tusuk \\
\hline G31 & $\begin{array}{l}\text { Benjolan-benjolan pada kulit } \\
\text { mengandung nanah }\end{array}$ \\
\hline G32 & Demam atau menggigil \\
\hline G33 & Bercak kemerahan \\
\hline G34 & Kulit kering dan melepuh \\
\hline G35 & $\begin{array}{l}\text { Luka lecet pada bokong, paha } \\
\text { maupun alat kelamin }\end{array}$ \\
\hline G36 & $\begin{array}{l}\text { Kulitnya teraba hangat ketika } \\
\text { disentuh }\end{array}$ \\
\hline G37 & Popok yang lembab \\
\hline G38 & Popok terlalu ketat \\
\hline Infeksi bakteri dan jamur \\
\hline Kulit sensitive \\
\hline Iritasi produk kebersihan bayi \\
\hline G41
\end{tabular}

\section{Relasi/Rule Penyakit dan Gejala Kulit}

Dari data penyakit dan gejala yang ada dapat dipersingkat informasinya menjadi tabel keputusan yang isinya adalah relasi atau hubungan antara penyakit dengan gejalanya yang dapat dilihat pada tabel berikut.

Tabel 3. Tabel Relasi/Rule Data Penyakit Data Gejala

\begin{tabular}{|c|c|c|c|c|c|c|c|}
\hline ID_- & \multicolumn{7}{|c|}{ Kode Penyakit } \\
\cline { 2 - 8 } $\begin{array}{c}\text { Gejal } \\
\text { a }\end{array}$ & P1 & P2 & P3 & P4 & P & P6 & P7 \\
\hline G01 & $*$ & $*$ & $*$ & $*$ & $*$ & $*$ & $*$ \\
\hline G02 & $*$ & $*$ & & & & $*$ & \\
\hline
\end{tabular}




\begin{tabular}{|l|l|l|l|l|l|l|l|}
\hline $\mathrm{G} 03$ & $*$ & & & & & & \\
\hline $\mathrm{G} 04$ & $*$ & & & & & & \\
\hline $\mathrm{G} 05$ & $*$ & & & & & & \\
\hline $\mathrm{G} 06$ & $*$ & $*$ & & & & & \\
\hline $\mathrm{G} 07$ & & $*$ & $*$ & & & $*$ & \\
\hline $\mathrm{G} 08$ & & $*$ & & & & & \\
\hline $\mathrm{G} 09$ & & $*$ & & & & & \\
\hline $\mathrm{G} 10$ & & $*$ & & & & & \\
\hline $\mathrm{G} 11$ & & $*$ & & & & & \\
\hline $\mathrm{G} 13$ & & $*$ & & & & & \\
\hline $\mathrm{G} 14$ & & & $*$ & & & & \\
\hline $\mathrm{G} 15$ & & & $*$ & & & & \\
\hline $\mathrm{G} 16$ & & & $*$ & & & & \\
\hline $\mathrm{G} 17$ & & & $*$ & & & & \\
\hline $\mathrm{G} 18$ & & & $*$ & & & & \\
\hline $\mathrm{G} 19$ & & & $*$ & & & & \\
\hline $\mathrm{G} 20$ & & & $*$ & & $*$ & & \\
\hline $\mathrm{G} 21$ & & & $*$ & & & & \\
\hline $\mathrm{G} 22$ & & & & $*$ & & & \\
\hline $\mathrm{G} 23$ & & & & $*$ & & & \\
\hline $\mathrm{G} 24$ & & & & $*$ & & & \\
\hline $\mathrm{G} 25$ & & & & & $*$ & & \\
\hline $\mathrm{G} 26$ & & & & & $*$ & & \\
\hline $\mathrm{G} 27$ & & & & & $*$ & & \\
\hline $\mathrm{G} 28$ & & & & & $*$ & & \\
\hline $\mathrm{G} 29$ & & & & & & $*$ & \\
\hline $\mathrm{G} 30$ & & & & & & $*$ & \\
\hline $\mathrm{G} 31$ & & & & & & $*$ & \\
\hline $\mathrm{G} 32$ & & & & & & $*$ & \\
\hline $\mathrm{G} 33$ & & & & & & & $*$ \\
\hline $\mathrm{G} 34$ & & & & & & & $*$ \\
\hline $\mathrm{G} 35$ & & & & & & & $*$ \\
\hline $\mathrm{G} 36$ & & & & & & & $*$ \\
\hline $\mathrm{G} 37$ & & & & & & & $*$ \\
\hline $\mathrm{G} 39$ & & & & & & & $*$ \\
\hline
\end{tabular}

\subsection{Perancangan Aplikasi}

\section{Use Case}

Berikut adalah tampilan perancangan use case yang merupakan alur sistem pada sistem pakar diagnosa penyakit kulit pada balita, yang disajikan dalam gambar berikut ini :
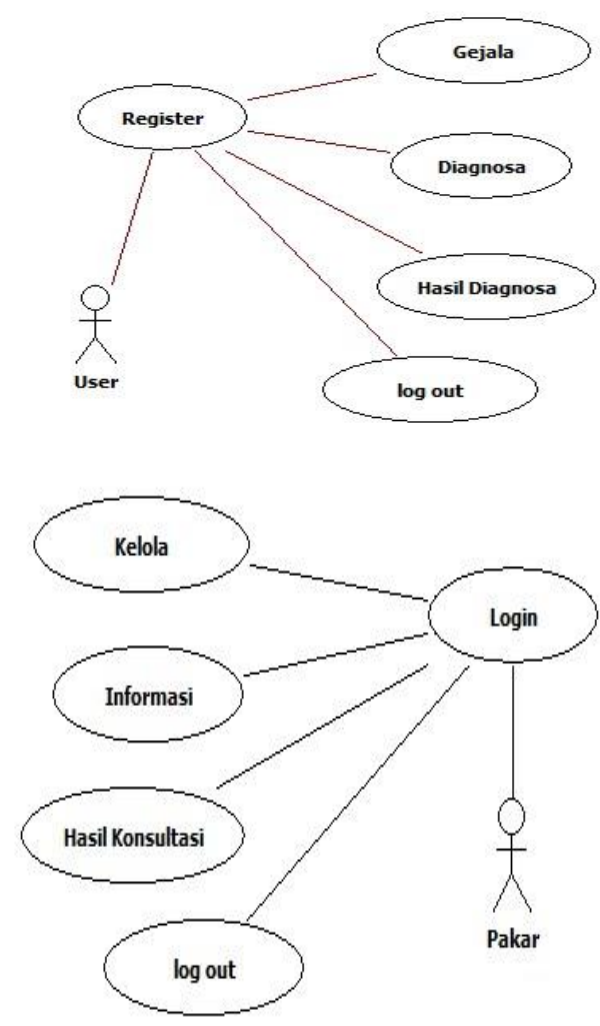

Gambar 4. Use Case Diagram

\section{Diagram Activity}

Berikut adalah rancangan diagram activity yang disajikan dalam gambar berikut ini :

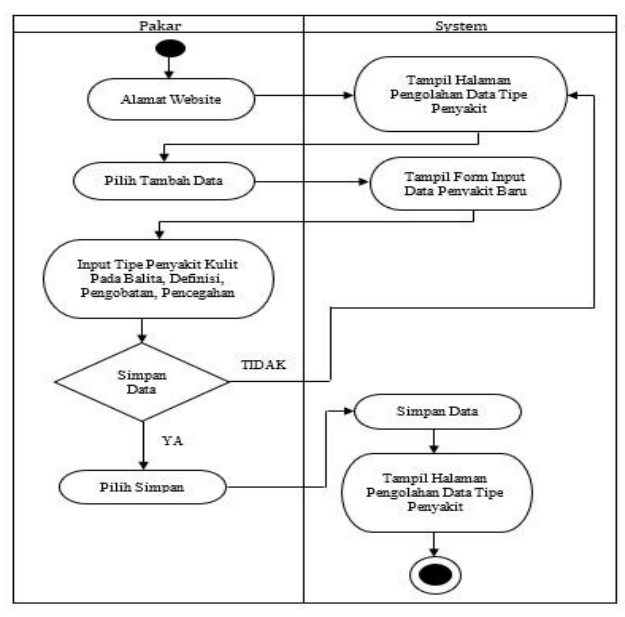

Gambar 5. Diagram activity 


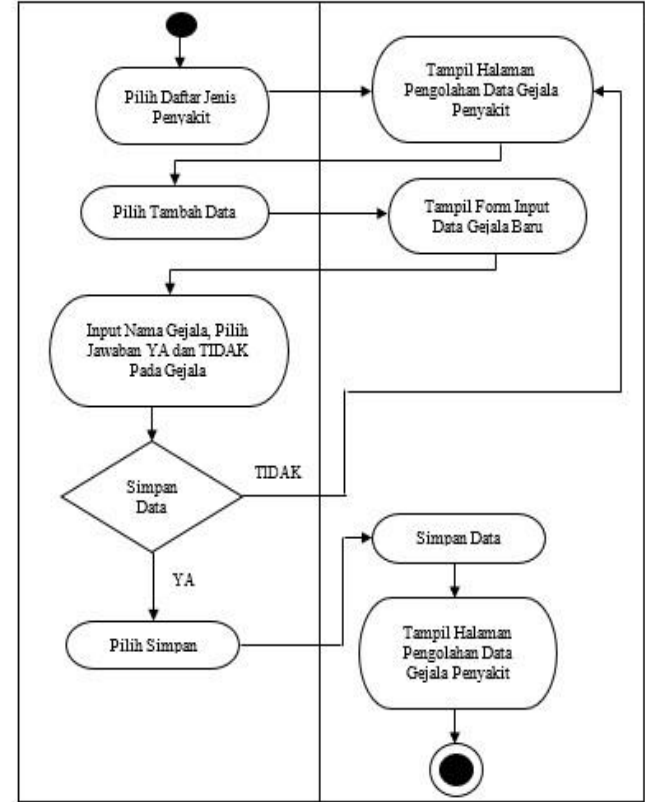

Gambar 6. Diagram Activity Pengolahan Daftar Gejala

\section{Class Diagram}

Rancangan database yang digunakan pada peancangan system sistem pakar ini adalah:

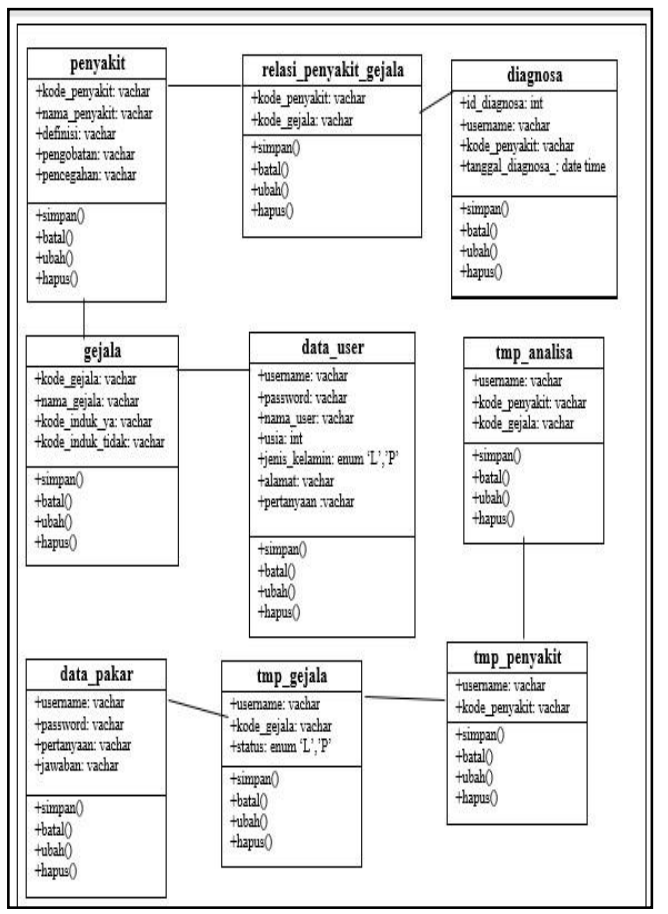

Gambar 7. Class Diagram

\section{HASIL DAN PEMBAHASAN}

\section{a. Login admin}

Berikut adalah gambar Login Admin yang ada di system dan disajikan dalam gambar 8 berikut ini

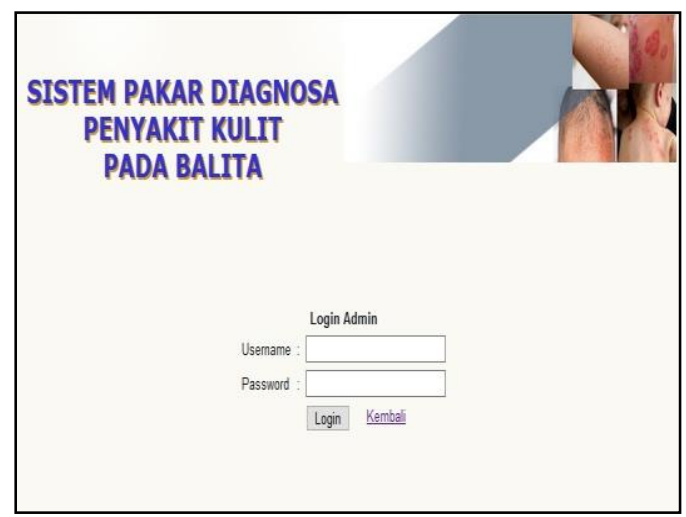

Gambar 8. Tampilan login admin

Halaman login pakar ini ada dihalaman login admin. Tampilannya berbeda dengan registrasi user. Login pakar ini berguna sebagai sesion admin sebelum dapat masuk ke halaman pakar untuk mengelola aplikasi. Tampilan login pakar. Untuk dapat masuk menggunakan Username dan password yang sudah dibuat kemudin pilih login.

b. Halaman Home/dashboard pakar Berikut adalah gambar home/dashboard user pada yang ada pada system, disajikan dalam gambar berikut ini

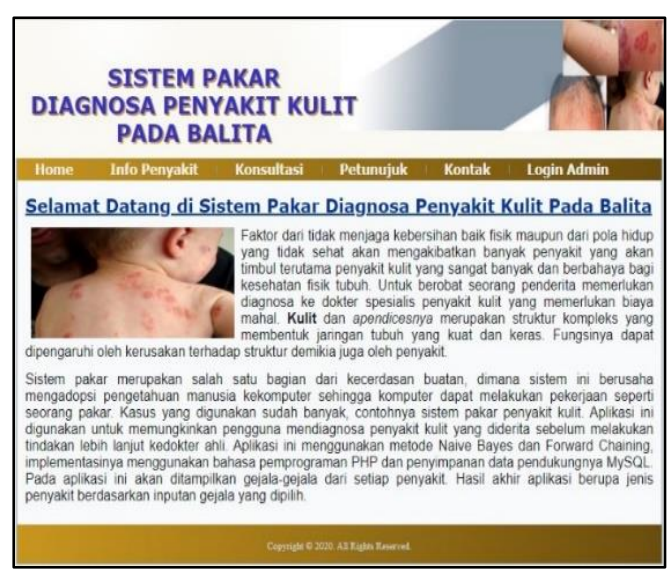




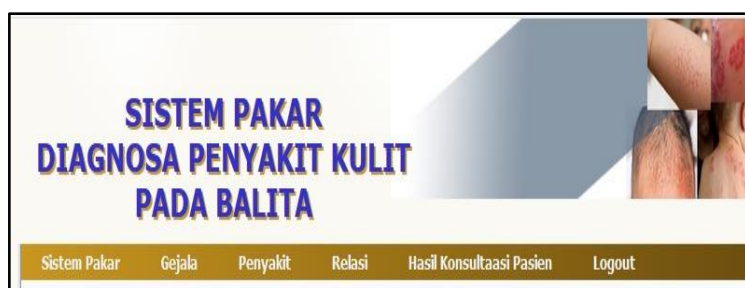

Selamat Datang di Administrator

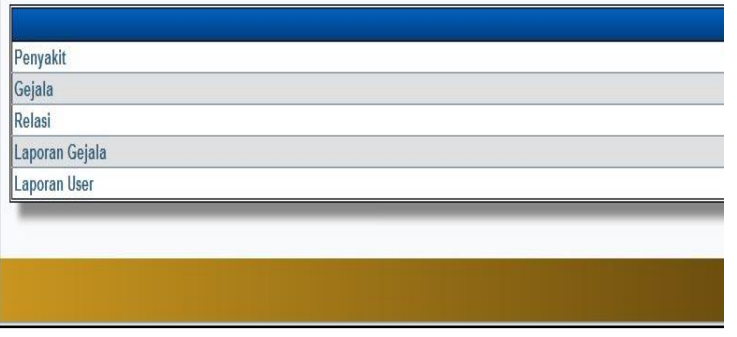

Gambar 9. Tampilan home/dashboard

Halaman utama ini berisi ucapan selamat datang dari website. Pada halaman ini user tidak dapat melihat tampilan menu ini hanya admin yang dapat melihat halaman utama penyakit kulit pada balita.

\section{c. Halaman data kelola}

Berikut adalah gambar Data Kelola penyakit dan solusi serta data gejla pada sistem pakar diagnosa penyakit kulit pada balita, disajikan dalam gambar 10 dan 11 berikut ini

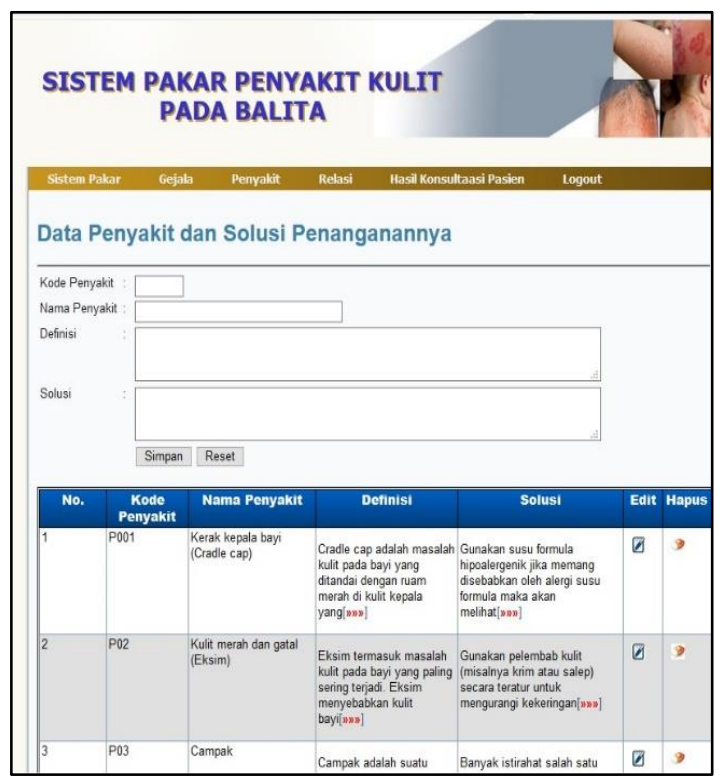

Gambar 10. Tampilan data Kelola penyakit

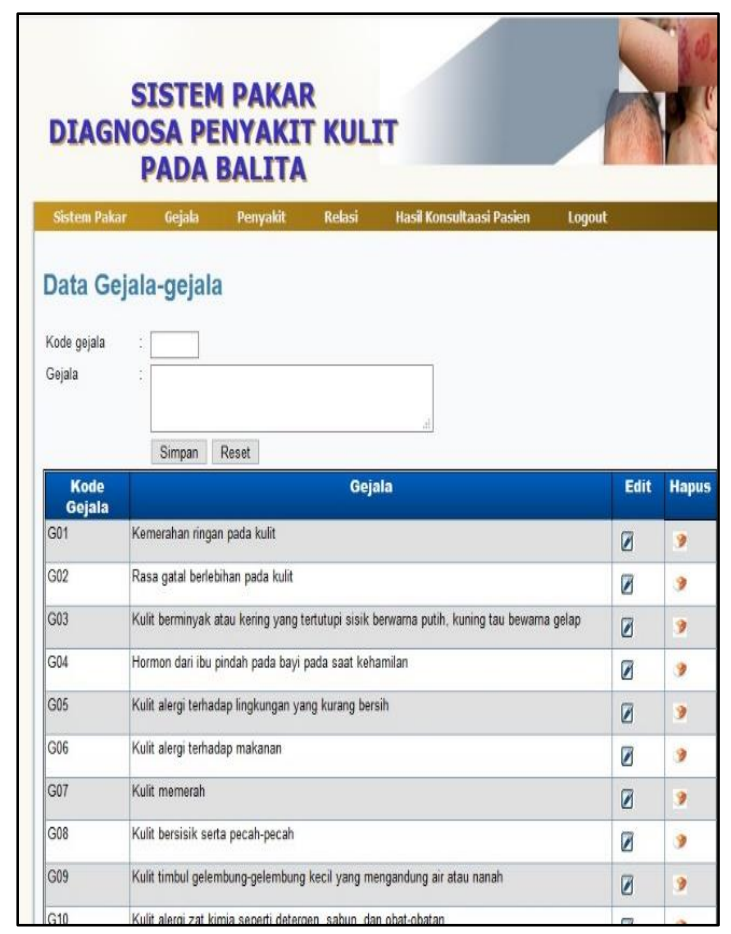

Gambar 11. Tampilan data Kelola gejala

\section{d. Info penyakit}

Halaman Info penyakit sama halnya dengan menu utama hanya saja didalam info penyakit ini lebih membahas ke penyakit.

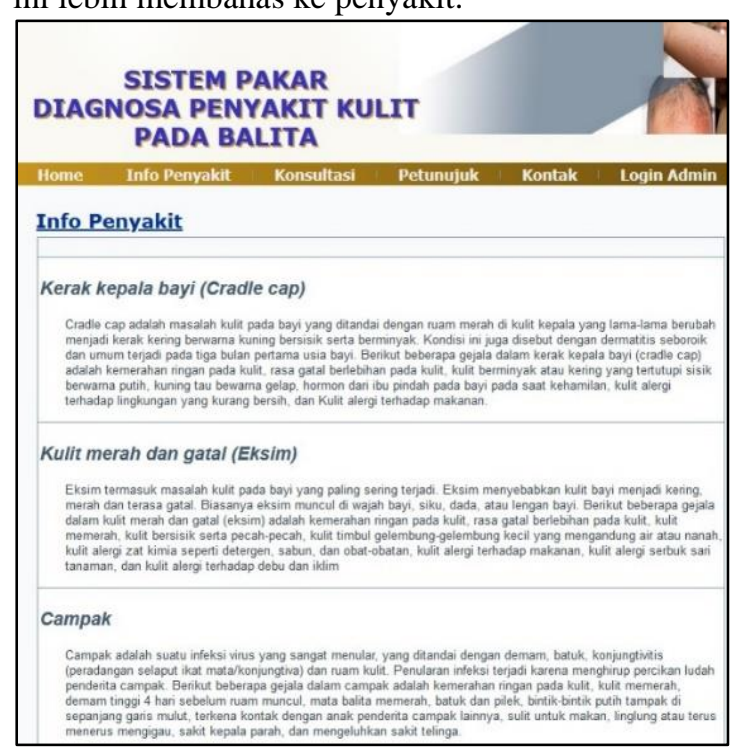

Gambar 12. Tampilan info penyakit

\section{e. Halaman konsultasi/Registrasi}


Pada saat pasien akan melakukan konsultasi maka terlebih dahulu harus melakukan registrasi yaitu dengan mengisi nama, jenis kelamin, umur alamat, nomor hp. Dengan menekan tombol register

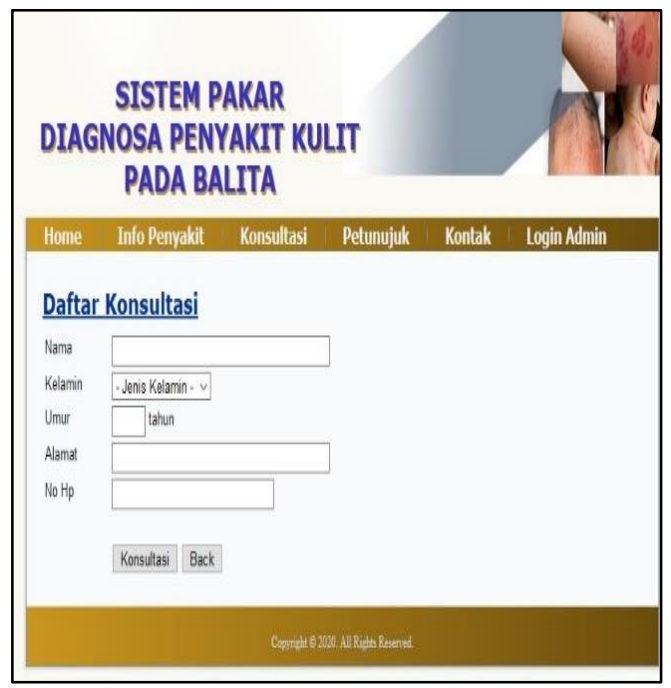

Gambar 13. Tampilan konsultasi/Registrasi

\section{g. Halaman diagnosa penyakit}

Berikut ini adalah halaman diagnosa penyakit kulit pada balita yang, disajikan pada gambar berikut ini

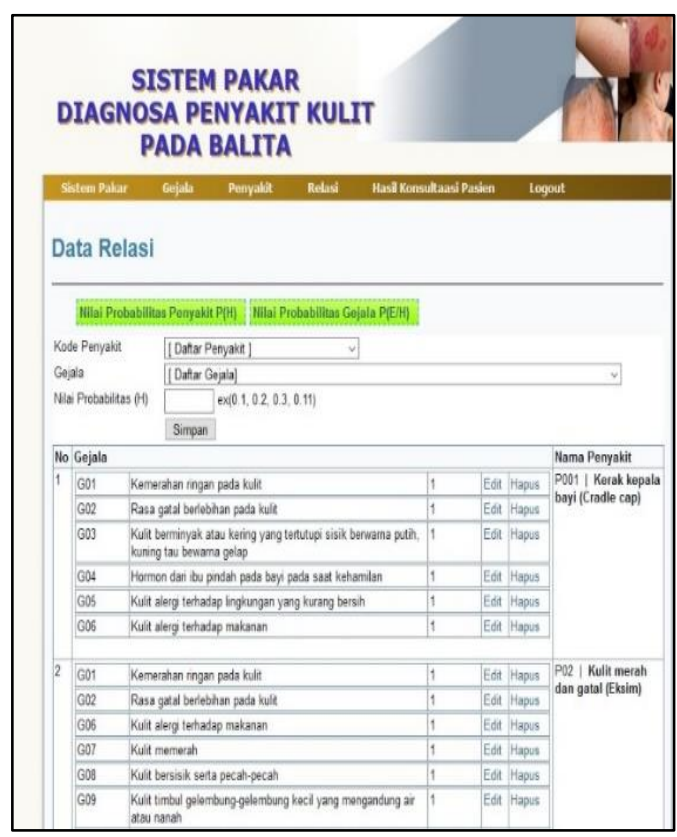

Gambar 13. Halaman Diagnosa

\section{h. Hasil Diagnosa}

Berikut adalah hasil diagnosa pada system yang disajikandakan ganbar di bawah ini

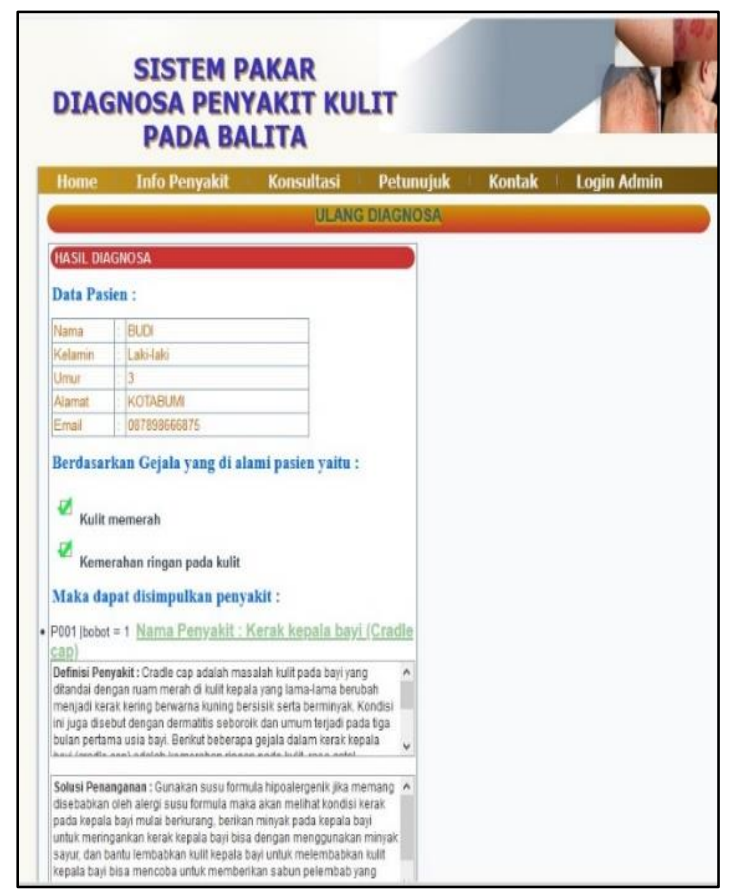

\section{Kesimpulan dan Saran}

Berdasarkan hasil penelitian dan pembahasan dapat ditarik kesimpulan adalah sebagai berikut sistem pakar diagnosa penyakit kulit dapat mendeteksi penyakit kulit pada balita berdasarkan gejala, jenis penyakit dan rule, system pakar dapat memberikan keterangan dan solusi terhadap penyakit.

System pakar dapat membantu orang tua untuk mengetahui penyakit kulit pada balita yang diderita secara awal sebelum bertemu dengan pakar atau dokter.

Berikut ini adalah saran:

a. Pengembangan sistem pakar ini sebaiknya harus dapat mencakup semua jenis penyakit kulit beserta dengan gejala yang lebih lengkap.

b. Aplikasi ini juga dapat dikembangkan dengan berbasis android sehingga dapat memudahkan pengguna.

c. Penambahan contoh gambar pada hasil diagnosa dapat dilakukan sehingga menjadi contoh bagi user untuk menentukan diagnosa yang dihasilkan sesuai atau tidak. 


\section{DAFTAR PUSTAKA}

[1] F. Yanto, I. Werdiningsih, and E. Purwanti, "Aplikasi Sistem Pakar Diagnosa Penyakit Pada Anak Bawah Lima Tahun Menggunakan Metode Forward Chaining," J. Inf. Syst. Eng. Bus. Intell., vol. 3 , no. 1, p. 61 , 2017, doi: 10.20473/jisebi.3.1.61-67.

[2] R. Rismanto, Y. Yunhasnawa, and M. Mauliwidya, "Pengembangan Sistem Pakar Untuk Diagnosa Penyakit Kulit Pada Manusia Menggunakan Metode Naive Bayes," J. Ilm. Teknol. Inf. dan Robot., vol. 1, no. 1, pp. 18-24, 2019,

doi: 10.33005/jifti.v1i1.8.

[3] E. Dewi, S. Mulyani, and I. N. Restianie, "Aplikasi Sistem Pakar Untuk Mendiagnosa Penyakit Anak (Balita) Dengan Menggunakan metode Forward Chaining," vol. 1, no. 1, pp. 6-7, 2012.

[5] Y. K. P, "Sistem Pakar Diagnosa Penyakit Kulit," vol. 2, no. 1, pp. 21-26, 2017.

[6] A. A. S. Nugraha, N. Hidayat, and L. Fanani, "Sistem Pakar Diagnosis Penyakit Kucing Menggunakan Metode Naive Bayes - Certainty Factor Berbasis Android," $J$. Pengemb. Teknol. Inf. dan Ilmu Komput. Univ. Brawijaya, vol. 2, no. 2, pp. 650-658, 2018.

[7] Ashari and A. Y. Muniar, "Penerapan Sistem Pakar Untuk Mendiagnosa Penyakit Pencernaan Dengan Pengobatan Bahan Alami," Semin. Nas. Sains dan Teknol. 2016, no. November, pp. $2407-$ 1846, 2016.

[8] W. Bagye, M. Salehudin, and K. Imtihan, "Implementasi Sms Gateway Pada Sistem Informasi
Kesiswaan Sekolah Menengah Atas Negeri (Sman) 1 Praya Tengah Menggunakan Metode Extreme Programming (Xp)," J. Manaj. Inform. dan Sist. Inf., vol. 2, no. 2, p. 27, 2019, doi: 10.36595/misi.v2i2.101.

[9] H. W. Putra, "Sistem Pakar Diagnosis Penyakit Ginjal Dengan Metoda Forward Chaining," $J$. Sains dan Inform., vol. 5, no. 1, p. $7, \quad 2019, \quad$ doi: 10.22216/jsi.v5i1.4081. 